\title{
Noncatalytic biodiesel synthesis from rubber seed oil via supercritical methanol and ethanol
}

- Tran Tan Viet $^{1}$

- Le Thi Kim Phung ${ }^{1}$

- Pham Tuan Anh ${ }^{2}$

- Tran Anh Khoa ${ }^{1}$

${ }^{1}$ Faculty of Chemical Engineering, Hochiminh City University of Technology, VNU-HCM

${ }^{2}$ Faculty of Transportation Engineering, Hochiminh City University of Technology, VNU-HCM

(Manuscript Received on July, 2016, Manuscript Revised on September, 2016)

\begin{abstract}
This paper reports the production of fatty acid methyl esters (FAMEs) and fatty acid ethyl esters (FAEEs) by the transesterification reaction of rubber seed oil (RSO) in supercritical methanol and ethanol without using any catalyst. Experiment were carried out in a batch reactor, and reactions were studied at 260, 280, 300 and $320^{\circ} \mathrm{C}$ at a pressure of 8.1 $19 \mathrm{MPa}$ with various mole ratios of ethanol - to

- methanol from 0 to $100 \%$. The extent of the reaction was explored using a convertibility parameter, which corresponds to the maximum ester content attainable from the feedstock. The highest FAME and FAEE contents achieved were $91.8 \%$ and $86.4 \%$, respectively. Results show that transesterification of RSO in methanol was more efficient than that in ethanol; the temperature had the strongest influence.
\end{abstract}

Keywords: biodiesel, supercritical, ethanol, methanol, rubber seed oil.

\section{INTRODUCTION}

The transesterification of vegetable oil using an alcohol at supercritical conditions comprises a method used to produce biodiesel and has gained growing interest due to the benefits related to the environment and quality of the fuel generated [1-4]. Alcohol provides the alkyl group that substitutes the fatty fraction of triglyceride and short chain alcohols such as methanol, ethanol, and butanol are the most frequently employed. There are several sources of vegetable oil suitable for production of biodiesel such as palm oil, jatropha, soy bean and some selected species of forest seeds. Recently, the European Union is critical to the biofuel production using edible oils such as palm oil, corn, soy bean and maize, which are also consumed as food. These open a new avenue of producing a biodiesel using a non- 
food source crop such as the seed of the rubber tree (HeveaBrasiliensis).

The rubber seed oil has a high free fatty acid content, which mean the use of alkaline catalysts such as sodium hydroxide to produce biodiesel is unfavorable [5] because of the formation of relatively large amounts of soaps, leading to product loss and difficulty in the separation and purification of the biodiesel produced [6]. Thus, this work aims to overcome this issue by applying the catalyst-free transesterification reaction in supercritical alcohol condition.

The catalyst-free alcoholysis reactions at supercritical methanol conditions provide improved phase solubility, decrease masstransfer limitations, afford higher reaction rates and make the separation and purification steps of the products easier. Additionally, it has been shown that the supercritical method is more tolerant to the presence of water and free fatty acids than the conventional alkali-catalyzed technique, and hence more tolerant to various types of vegetable oils [7,8]. However, the supercritical methanol method requires high molar ratios of methanol to oil and the use of high temperatures and pressures to achieve satisfactory conversion levels, leading to high processing costs and in many cases causing degradation of the fatty acid esters formed and secondary reactions with the glycerol formed as byproduct, hence decreasing the reaction conversion [9-11]. Attempts to reduce the expected high operating cost and product degradation have been made through the addition of co-solvents such as ethanol, $\mathrm{CO}_{2}$ or water [12-14]. From an engineering point of view, ethyl ester (from transesterification reaction with ethanol) utilization is also more advantageous than the utilization of methyl esters because of the agricultural renewable resources and the ability of dissolving oils. Therefore, ethanol is sometimes used as a suitable alcohol for the transesterification of vegetables oils.

In this context, the main objective of this work is to investigate the effect of ethanol in the synthesis biodiesel from RSO under supercritical methanol-ethanol conditions.

\section{METHOD}

\subsection{Materials}

RSO is pressed from the seeds in Binh Phuoc Province, Vietnam on December 2015. Oil is dark yellow color, not impurities and used as a feedstock directly for reaction. Oil sample was analyzed to determine composition of fatty acids by gas chromatography GC-MS analysis and showed on Table 1

Table 1. Composition of fatty acids in RSO

\begin{tabular}{|l|l|l|}
\hline \multicolumn{1}{|c|}{ Fatty acid } & Formula & \multicolumn{1}{|c|}{$\begin{array}{c}\text { Composition } \\
\text { (wt. \%) }\end{array}$} \\
\hline $\begin{array}{l}\text { Palmitic Acid } \\
\left(\mathrm{C}_{16: 0}\right)\end{array}$ & $\mathrm{C}_{16} \mathrm{H}_{32} \mathrm{O}_{2}$ & 10.114 \\
\hline $\begin{array}{l}\text { Stearic Acid } \\
\left(\mathrm{C}_{18: 0}\right)\end{array}$ & $\mathrm{C}_{18} \mathrm{H}_{36} \mathrm{O}_{2}$ & 10.672 \\
\hline $\begin{array}{l}\text { Oleic Acid } \\
\left(\mathrm{C}_{18: 1}\right)\end{array}$ & $\mathrm{C}_{18} \mathrm{H}_{34} \mathrm{O}_{2}$ & 24.407 \\
\hline $\begin{array}{l}\text { 11-Octadecen } \\
\text { oic Acid, (Z) } \\
\left(\mathrm{C}_{18: 1}\right)\end{array}$ & $\mathrm{C}_{18} \mathrm{H}_{34} \mathrm{O}_{2}$ & 1.562 \\
\hline $\begin{array}{l}\text { Linoleic Acid } \\
\left(\mathrm{C}_{18: 2}\right)\end{array}$ & $\mathrm{C}_{18} \mathrm{H}_{32} \mathrm{O}_{2}$ & 37.986 \\
\hline $\begin{array}{l}\text { Linolenic } \\
\text { Acid }\left(\mathrm{C}_{18: 3}\right)\end{array}$ & $\mathrm{C}_{18} \mathrm{H}_{30} \mathrm{O}_{2}$ & 15.259 \\
\hline
\end{tabular}

Methanol and ethanol (grade: Chromasolv) was purchased from Sigma-Aldrich; the critical point of methanol and ethanol are $239.6{ }^{\circ} \mathrm{C}, 8.09$ $\mathrm{MPa}$ and $240.9^{\circ} \mathrm{C}, 6.14 \mathrm{MPa}$ respectively [15].

\subsection{Apparatus and experimental procedure}




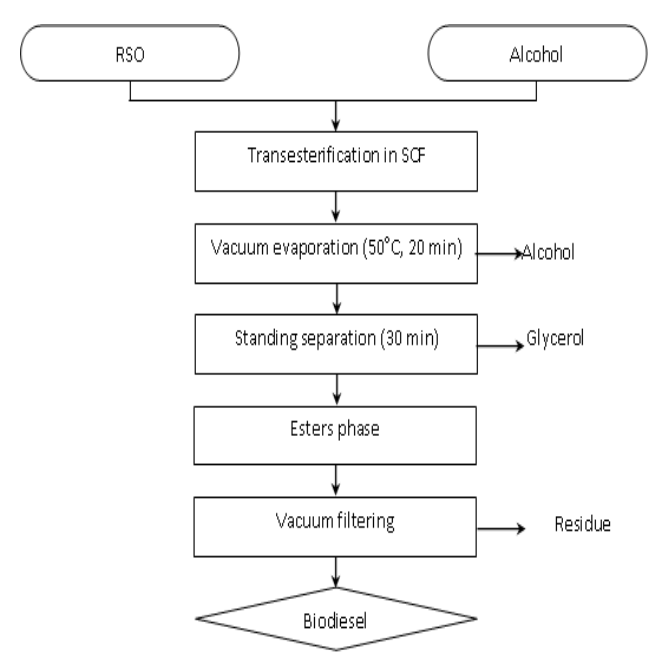

Figure 1. Diagram of biodiesel preparation from RSO using supercritical alcohol

A Parr Instruments 4546 series, high pressure 1.2-L reactor, made of tempered 316stainless steel and rated at $350{ }^{\circ} \mathrm{C}$ and 2,000 psi (13.79 MPa), was employed in this study and the stirring speed was set at a fixed level for all experiment, $300 \mathrm{rpm}$. For each experiment, the vessel was charged with a given amount of RSO and liquid alcohol with different molar ratios. The range of temperature and pressure studied was between $260-320{ }^{\circ} \mathrm{C}$ and $7.8-9.8 \mathrm{MPa}$, respectively. After a fixed reaction time period (from 2 to $50 \mathrm{~min}$ ), the vessel was removed from the heater and cooling water was supplied in the spiral cooling-coil to quickly cool the reactor, thus quenching the reaction and depressurizing to ambient pressure.

The mixture of product was evaporated at $50{ }^{\circ} \mathrm{C}$ for $20 \mathrm{~min}$ by the vacuum equipment to remove and recover the remaining alcohol. This mixture was then allowed to settle for about 30 min to have the two phases separated: the top phase consists of the biodiesel (fatty acid methyl/ethyl esters) and the lower phase consists of the glycerol and other minor components.
According to the diagram in Figure 1, experiments were carried out repeated three times for each variable point in order to confirm the resulted data.

\subsection{Analysis of fatty acid methyl ester (FAME), fatty acid ethyl ester (FAEE) \\ GC/MS analysis was used to determine} fatty acid components. The fatty acid methyl esters (FAME) and fatty acid ethyl esters (FAEE) were prepared by trans-esterification of oil with $2 \mathrm{~N} \mathrm{KOH}$ in methanol and n-hexane. Gas chromatographic (GC) analysis of FAME were performed in THERMO TRACE GC ULTRA equipped with a TR-Fame column (Agilent, USA) (30m, $0.32 \mathrm{~mm}$ Internal diameter, film thickness $0.20 \mu \mathrm{m}$ ), a split injector at $250{ }^{\circ} \mathrm{C}$; mass spectrometry detector at $250{ }^{\circ} \mathrm{C}$. Helium was used as carrier gas with flow rate at $1 \mathrm{ml} / \mathrm{min}$ and the split ratio was used PTV Split program. The programmed temperature: oven was maintained at $100 \circ \mathrm{C}$ for $3 \mathrm{~min}, 100-220^{\circ} \mathrm{C}$ at $20^{\circ} \mathrm{C} / \mathrm{min}$ (7 min), 220$250{ }^{\circ} \mathrm{C}$ at $5^{\circ} \mathrm{C} / \mathrm{min}(5 \mathrm{~min})$. The identification of FAME was based on library.

\section{RESULTS AND DISCUSSIONS}

\subsection{Effect of temperature on the yield of biodiesel}

Temperature plays a critical role in alcoholysis reaction at supercritical state for biodiesel production. As the critical point of methanol is higher than the critical ethanol point (239.6 ${ }^{\circ} \mathrm{C}, 8.09 \mathrm{MPa}$ and $240.9{ }^{\circ} \mathrm{C}, 6.14 \mathrm{MPa}$ respectively), all the experiments condition (the reaction temperature and the reaction pressure) were higher than these critical values to ensure that supercritical alcohol condition were reached. Figure 1 presents the effect of temperature on the yield of biodiesel at 
transesterification reaction in supercritical alcohol (methanol, ethanol and mixture ethanolmethanol with 50:50 mole ratio) condition which were carried out at 20 minutes reaction time and 40:1 molar ratio of alcohol to oil.

For supercritical methanol (SCM) condition, the ester content of biodiesel increased with temperature lower than $280{ }^{\circ} \mathrm{C}$ with the maximum value of $91.8 \mathrm{wt} \%$. Beyond the optimum temperature, the ester content decreased slightly to $89.9 \mathrm{wt} \%$ at $320{ }^{\circ} \mathrm{C}$. In addition, similar trend is observed for supercritical ethanol (SCE) condition but the optimum temperature is relatively lower at 280 ${ }^{\circ} \mathrm{C}$, with optimum ester content of $86.4 \%$. Compare with SCM condition reaction, the ester content of reaction product were lower when supercritical mixture $50 \%$ ethanol-50\% methanol was used. The highest ester content was $87.7 \%$ at $280{ }^{\circ} \mathrm{C}$ and the ester yield decrease with the increase of reaction temperature. This observation can be explained by the activity of triglycerides with alcohol, which decreases with increasing alkyl chain of alcohol. There is similar with the result of Warabi et al. [16] and the reason might be due to the long chain alkyl group hindering the alcohol group from reacting with triglycerides to form fatty acid alkyl esters. Hence, supercritical alcohol reaction has lower optimum yield of biodiesel when increased the ratio of ethanol in the mixture from 0 to $100 \%$

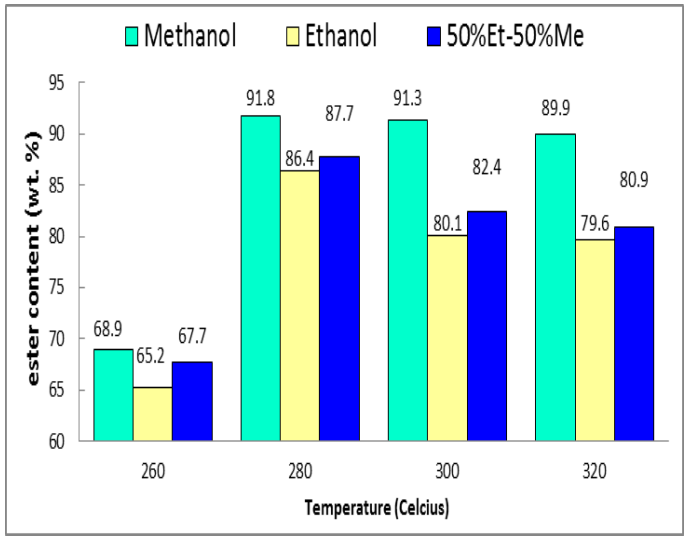

Figure 2. Effect of the reaction temperature on ester content (molar ratio alcohol:oil 40:1, reaction time 20 $\min )$.

\subsection{Effect of reaction time on the yield of biodiesel}

Beside the temperature, the effect of the reaction time on the conversion efficiency in biodiesel production with supercritical alcohol follows the general rate law. Compared to two steps conventional catalytic reactions which required near 2 hours of reaction time, supercritical alcohol reaction can be completed in a substantially lower duration of 20 minutes.

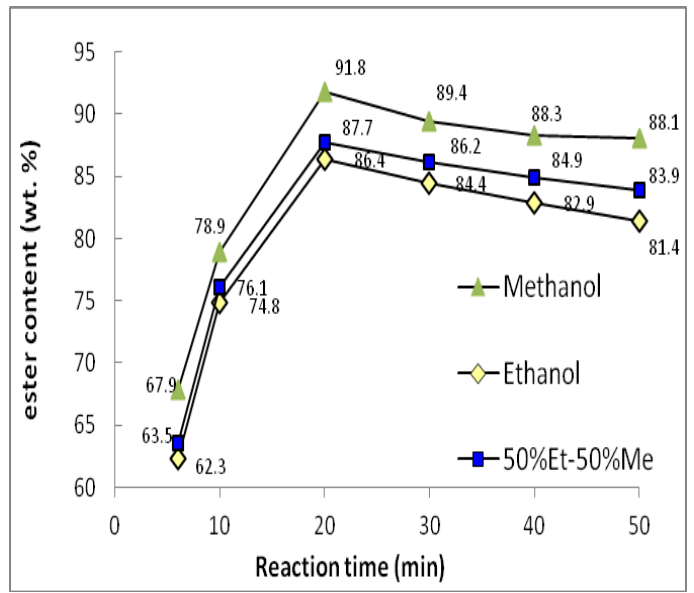

Figure 3. Effect of the reaction time on methyl ester content (molar ratio alcohol:oil 40:1, reaction temperature $280{ }^{\circ} \mathrm{C}$ ). 
The effects of reaction time on the transesterification reaction were investigated at $6,10,20,30,40,50$ minute with fixed temperature $280{ }^{\circ} \mathrm{C}$ and alcohol : oil ratio of 40:1. Figure 3 shows an example of the relationship between the reaction time and the various supercritical alcohol. It was observed that the yield of biodiesel increased steadily with the increment of time until the optimum conditions of around 20 minutes. In addition , the value of ester content decreases with the increases ratio of ethanol in the mixture supercritical media from $0 \%$ to $50 \%$ and finally $100 \%$ (only ethanol in the mixture). At the optimum condition, the yields of biodiesel were $91.8 \%, 86.4$ and $87.7 \%$ for SCM, SCE and supercritical mixture $50 \%$ methanol - 50\% ethanol respectively. Beyond the optimum reaction time, the yield of biodiesel decreased gradually due to the instability of produced biodiesel at high temperature for a long period of time. In addition, it can be interpreted in two reasons: firstly, the reaction reached the equilibrium, as increasing the reaction time could shift the reaction to the opposite direction, i.e. the reverse reaction of transesterification because product and glycerin were not separated from each other; secondly, in the composition of RSO contains a large amount of unsaturated fatty acids, which was low in oxidized durability, the side reactions may occur to degrade the obtained yield of methyl ester with extended time.

\subsection{Effect of the alcohol to RSO molar ratio on the yield of biodiesel}

The stoichiometric ratio for the transesterification reaction requires three moles of alcohol and one mole of triglyceride to yield three moles of fatty acid ester and one mole of glycerol. Since the transesterification is an reversible reaction, the amount of alcohol reactant in fact is higher than in theory in order to shift the reaction to the product side. Because the critical point of oil and alcohol mixture is reduced when the alcohol: oil molar ratio increased, the FAME and FAEE content is enhanced as constant temperature and pressure. On the other hand, an excessive ratio of alcohol to oil also lowers the density of reaction mixture. In order to study the effects of alcohol: oil molar ratio on the transesterification, different alcohol: oil molar ratios as 10:1, 20:1, 30:1, 40:1and 50:1 were used with a fixed temperature of $280{ }^{\circ} \mathrm{C}$ and reaction time 20 minute and the results had shown in Figure 4.

From the figure, the yield increased steadily when the molar ratio increased for both SCM, SCE and supercritical mixture alcohol reactions. However, when the molar ratio exceeded the optimum value of 40 , the yield of biodiesel suffers a slight change. Although enormous amount of alcohol can enhanced the reaction rate, excessive concentration of alcohol in the reaction can inhibits transesterification reaction. This might be due to the thermodynamic equilibrium limitation and the difficulties in separating excessive alcohol from esters and glycerol. Hence, the molar ratio of alcohol to oil should be kept at 40 in supercritical alcohol transesterification reaction. The studied done by N. Aimaretti et al. also gave similar final conversions with the supercritical alcohol method [10]. 


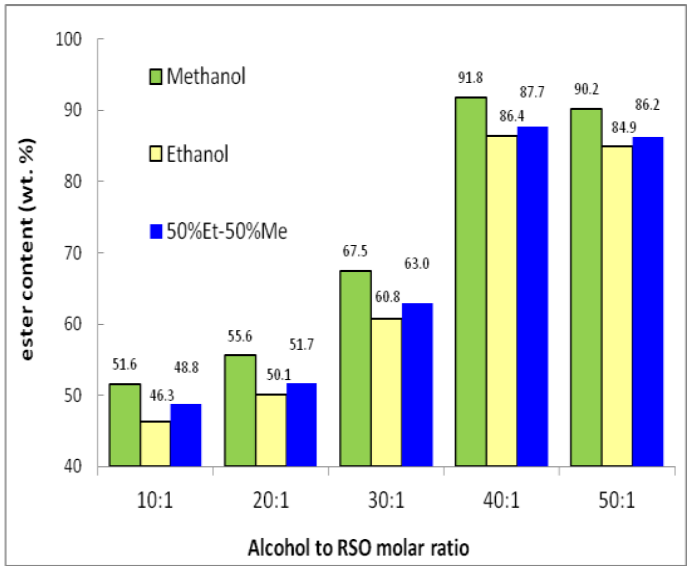

Figure 4. Effect of the alcohol to RSO molar ratio on ester content (reaction temperature $280{ }^{\circ} \mathrm{C}$, reaction time $20 \mathrm{~min}$ )

\subsection{Comparison between SCM, SCE and supercritical mixture methanol-ethanol reactions}

One of the objectives in this paper is investigates and compares reaction performance of RSO transesterification under supercritical mixture ethanol-methanol with various percentage ethanol from 0 to $100 \%$.

Ethanol is a preferred alcohol in the synthesis biodiesel process compared with methanol because it is derived from agricultural product and is renewable and biologically less objectionable in the environment and low toxicity. However, the SCM is significantly better than SCE in terms of biodiesel yield. The supercritical mixture of methanol - ethanol condition would be increased the yields of transesterification product but lower operation pressure in comparison with SCE condition.

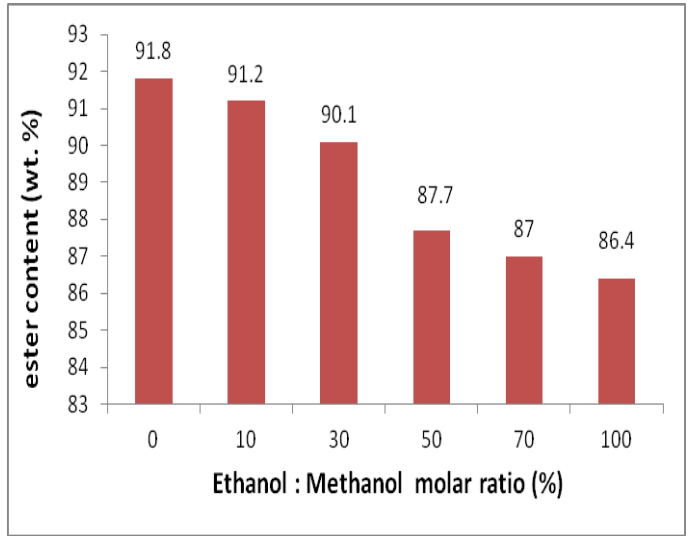

Figure 5. Effect of the percentage of ethanol in alcohol mixture on ester content (reaction temperature $280{ }^{\circ} \mathrm{C}$, reaction time $20 \mathrm{~min}$ and molar ratio alcohol:oil 40:1)

The transesterification using mixture alcohol in supercritical condition was carried out at the same operating conditions of the previous work using methanol (reaction temperature: 280 ${ }^{\circ} \mathrm{C}$, reaction time: 20 minute, alcohol:oil molar ratios as 40:1) with the comparison purpose. Figure 5 shows the ester content in the product obtained by transesterification of RSO in supercritical mixture methanol-ethanol with the percentage of ethanol from 0 to $100 \%$. It was observed that the yield of biodiesel decreases rapidly when the molar percentage of ethanol in the alcohol mixture is higher than $30 \%$. The lower yields valued in case of high amount of ethanol can be attributed to the problems in the purification step due to the higher inter solubility of the mixture. In addition, this might be due to the long chain alkyl group hindering the hydroxyl group in alcohol from reacting with triglycerides to form fatty acid alkyl ester.

Moreover, the percentage of ethanol in the mixture alcohol affected the reaction pressure strongly. Figure 6 shows an example of the relationship between the reaction pressure and 
the various percentage of ethanol in the mixture alcohol. It was observed that the percentage of ethanol in the mixture alcohol made the reaction pressure reduced steadily from $12.62 \mathrm{MPa}$ (SCM) to $7.52 \mathrm{MPa}$ (SCE). From the figure, the reaction pressure decreased gradually when the percentage of ethanol increased and, when the molar percentage of ethanol exceeded $30 \%$, the reaction pressure suffers a slight change. Few studies related the effect of pressure on the supercritical transesterification observed that pressure did not affect the transesterification conversion with supercritical alcohols [14].

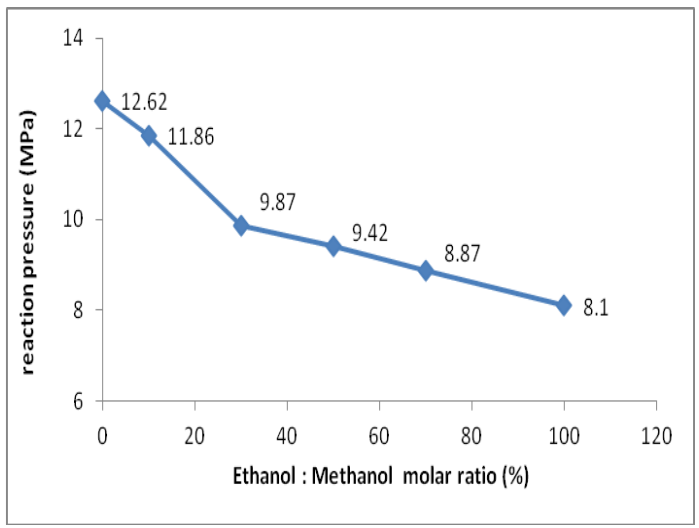

Figure 6. Effect of the percentage of ethanol in alcohol mixture on reaction pressure (reaction temperature $280{ }^{\circ} \mathrm{C}$, reaction time $20 \mathrm{~min}$ and molar ratio alcohol:oil 40:1)

\section{CONCLUSION}

Supercritical alcohol condition has been able to produce biodiesel by using methanol and ethanol as the source of alcohol. By comparing SCM and SCE processes, it was found that SCM is significantly better than SCE in terms of biodiesel yield. However, the mixture of alcohol reactants reduce significantly reaction pressure of transesterification reaction in supercritical alcohol to product biodiesel when increase the percentage of ethanol in alcohol. Therefore, the research can be concluded that reaction in supercritical mixture ethanol - methanol $(30 \%$ ethanol) is better and more suitable than SCE or $\mathrm{SCM}$ to be utilized in biodiesel production. 


\section{Tổng hợp biodiesel từ dầu hạt cao su không sử dụng xúc tác trong môi trường siêu tới hạn metanol và etanol}

- Trần Tấn Việt ${ }^{1}$

- Lê Thị Kim Phụng ${ }^{1}$

- Phạm Tuấn Anh ${ }^{2}$

- Trần Anh Khoa ${ }^{1}$

${ }^{1}$ Khoa Kỹ thuật Hóa học, trường Đại Học Bách Khoa, ĐHQG-HCM

${ }^{2}$ Khoa Kỹ thuật Giao thông, trường Đại Học Bách Khoa, ĐHQG-HCM

\section{TÓM TẮT}

Bài báo trình bày việc tổng hợp các metyl ester (FAMEs) và etyl ester (FAEEs) bằng phản úng chuyển vị ester tù nguyên liệu dầu hạt cao su (RSO) trong môi truò̀ng lưu chất siêu tới hạn của metanol và etanol mà không sủ dụng xúc tác. Các nghiên cưu được thực hiện trong thiết bị phản úng gián đoạn với các điều kiện nhiệt độ tù 260,280,300, $320{ }^{\circ} \mathrm{C}$ ơ áp suất trong khoảng 8,1 - 19 Mpa, tỉ lẹ mol của ethanol : methanol trong khoảng 0-100\%. Mức độ của các phản úng được nghiên cứu dựa vào độ

Tù khóa: dầu diesel sinh học, siêu tới hạn, ethanol, methanol, dầu hạt cao su. chuyển hóa để xác định luợng ester tối đa tạo ra tù nguồn nguyên liệu ban đầu. Luợng metyl ester FAME và etyl ester FAEE tối đa thu được trong quá trình phản ứng là $91,8 \%$ và $86,4 \%$. Kết quả nghiên cứu cho thấy phản ứng chuyển vị ester của RSO trong môi trừ̀ng siêu tới hạn metanol hiệu quả hơn so với thưc hiện phản ưng trong môi truòng etanol siêu tới hạn và nhiệt độ là thông số ảnh hưởng mạnh nhất đến mức độ phản úng.

\section{REFERENCES}

[1]. Wen D., Jiang H.,.Zhang K, Supercritical fluids technology for clean biofuel production. Prog. Nat. Sci., vol. 19, n. 3, 2009, 273-284.

[2]. Demirbas A., Biodiesel from vegetable oils via transesterification in supercritical methano, Energy Convers. Manage., vol. 43 , n. 17,2002 , .pp. 2349-2356
[3]. Madras G., Kolluru C., Kkumar R., Synthesis of biodiesel in supercritical fluids. Fuel, vol. 83, n. 14-15, 2004, pp. 2029-2033

[4]. Pinnarat T., Savage P., Assessment of noncatalytic biodiesel synthesis using supercritical reaction conditions, Ind. Eng. 
Chem. Res., vol. 47, n. 18, 2008, pp. 68016808.

[5]. Ramadhas A. S., Jayaraj S., and Muraleedharan C., Biodiesel production from high FFA rubber seed oil, Fuel, vol. 84, 2005, pp.335-340, March

[6]. Kouzu M., Kasuno T., Tajika M., Yamanaka S., and Hidaka, Active phase of calcium oxide used as solid base catalyst for transesterification of soybean oil with refluxing methanol Appl. Catal., A, vol.334, 2008, pp. 357-365,.

[7]. Vieitez I., Silva C., Alkimim I., Borges G.R., Corazza F.C., Oliveira J.V., Grompone M.A., Jachmanián I., Effect of temperature on the continuous synthesis of soybean esters under supercritical ethanol Energy Fuels, vol. 23, n. 1, 2009. pp. 558563 ,

[8]. Rathore V., Madras G., Synthesis of biodiesel from edible and non-edible oils in supercritical alcohols and enzymatic synthesis in supercritical carbon dioxide. Fuel, vol. 86, n. 17-18, 2007. pp. 26502659 ,

[9]. Imahara H., Minami E., Hari S., Saka S., Thermal stability of biodiesel in supercritical methanol. Fuel, vol. 87, n. 1, 2008, pp. 1-6.

[10].Aimaretti N., Manuale D.I., Mazzieri V.M., Vera C.R., Yori C., Batch study of glycerol decomposition in one-stage supercritical production of biodiesel. Energy Fuels, vol. 23, n. 2,2009, pp. 1076-1080.

[11].He H., Tao W., Zhu S.,Continuous production of biodiesel from vegetable oil using supercritical methanol process. Fuel, vol. 86, n. 3, 2007, pp. 442-447,.

[12].Cao W., Han H., Zhang J., Preparation of biodiesel from soybean oil using supercritical ethanol and cosolvent, Fuel, vol. 84, n. 4, 2005, pp. 347-351.

[13].Han H., Cao W., Zhang J., Preparation of biodiesel from soybean oil using supercritical methanol and $\mathrm{CO} 2$ as cosolvent, Process Biochem., vol. 40, n. 9, 2005, pp. 3148-3151.

[14].Vieitez I., Silva C., Borges G.R., Corazza F.C., Oliveira J.V., Grompone M.A., Jachmanián I., Continuous production of soybean biodiesel in supercritical ethanolwater mixtures. Energy Fuels, vol. 22, n. 4, 2008, pp. 2805-2809.

[15].Jessop P., Leitner W., Introduction. In Handbook of Green ChemistrySupercritical Solvents, Anastas, P.T., Leitner, W., Jessop, P., Eds.; Wiley-VCH Verlag GmbH\& Co: Weinheim, Germany, 2010; Volume 4, pp. 1-30.

[16].Silva C., Weschenfelder T.A., Rovani S., Corazza F.C., Corazza M.L., Dariva C., Oliveira J.V., Continuous production of fatty acid ethyl esters from soybean oil in compressed ethanol, Ind. Eng. Chem. Res., vol46, 2007, pp 5304-5309.

[17].Warabi Y., Kusdiana D., and Saka S., Reactivity of triglycerides and fatty acids of rapeseed oil in supercritical alcohols, Bioresour. Technol., vol. 91, 2004, pp.283287. 